\title{
PEMBENTUKAN KARAKTER BERBASIS KETELADANAN GURU DAN PEMBIASAAN MURID SIT AL BIRUNI JIPANG KOTA MAKASSAR
}

\author{
A.Sukmawati ${ }^{1,}$ H.M.Basri ${ }^{2}$, Muhammad Akhir ${ }^{3}$ \\ ${ }^{1-3}$ Jurusan Pendidikan Dasar Pascasarjana Unismuh Makassar, Indonesia \\ 12andi.sukmawati92@gmail.com
}

\begin{abstract}
Character building has been widely proclaimed by educational institutions. The teacher has a special position in shaping character values to create a generation of noble character. This study aims to determine the character formation based on the exemplary teacher and student habituation. This research is a qualitative type of phenomenological research. Data collection techniques carried out by observation, in-depth interviews, and documentation. Data analysis uses data reduction, data presentation and drawing conclusions. The results showed that the teacher's example was carried out through actions, such as discipline, maintaining success, being fair, wise, polite, polite in speaking, while students were accustomed to the school culture of greetings, salim, smiles and greetings, discipline, various religious activities, responsible, independent, honest and literacy activities. The impact that arises after the exemplary teacher and habituation of students gives birth to characters such as creating creative humans, increasing faith, changing attitudes for the better, being aware of the importance of literacy and loving the environment through social activities.
\end{abstract}

Keywords: Character, role models, habituation

\begin{abstract}
Abstrak: Pembentukan karakter telah banyak dicanangkan oleh lembaga pendidikan. Guru mempunyai kedudukan khusus dalam membentuk nilai-nilai karakter untuk menciptakan generasi yang berakhlak mulia. Penelitian ini bertujuan untuk mengetahui pembentukan karakter berbasis keteladanan guru dan pembiasaan murid. Penelitian ini termasuk penelitian kualitatif jenis fenomenologi. Teknik pengumpulan data dilakukan dengan cara observasi, wawancara mendalam, dan dokumentasi. Analisa data menggunakan reduksi data, penyajian data dan penarikan kesimpulan. Hasil penelitian menunjukkan bahwa keteladanan guru dilakukan melalui tindakan, seperti kedisiplinan, menjaga keberhasilan, adil, bijaksana, sopan,santun dalam bertutur, sedangkan murid dibiasakan sesuai budaya sekolah yaitu salam, salim, senyum dan sapa, disiplin, berbagai kegiatan keagamaan, bertanggung jawab, mandiri, jujur dan berkegiatan literasi. Dampak yang ditimbulkan setelah diberlakukan keteladanan guru dan pembiasaan murid melahirkan karakter seperti menciptakan manusia kreatif, meningkatkan keimanan, merubah sikap menjadi lebih baik, sadar akan pentingnya literasi dan cinta lingkungan melalui kegiatan social.
\end{abstract}

Kata Kunci: Karakter, keteladanan, Pembiasaan

\section{PENDAHULUAN}

Pendidikan merupakan hak manusia untuk mendapatkan ilmu pengetahuan, baik ilmu pengetahuan umum maupun pengetahuan ilmu agama, agar manusia dapat menggapai kebahagiaan hidupnya ketika di dunia dan kelak di akhirat, pendidikan diselenggarakan untuk menemukan generasi bangsa yang berakhlak mulia.

Setiap manusia mempunyai potensi bawaan, dan untuk mengetahui potensi yang ada pada setiap individu dikenal dengan isltilah, kenali potensi, gali kemudian tingkatkan sesuai dengan yang diinginkan melalui proses pencarian ilmu, di dasarkan pada pengalaman, cobaan, tantangan dan pengorbanan, dengan cara ini dapat ditemukan sesuat bernilai yang biasa di sebut dengan karakter. 
Karakter yang ada pada diri merupakan cerminan dari tingkah laku, jika seseorang memiliki karakter yang baik maka sikap baik pun akan terpancar dengan sendirinya ketika melakukan berbagai aktivitas, dilihat dari segi ucapan, orang yang memiliki karakter dan tingkah yang baik, akan berbicara dengan sopan secara spontan.

Proses pembentukan karakter tidak lepas dari nilai-nilai yang harus dimiliki oleh peserta didik dan diamalkan dalam kehidupan sehari-hari. Nilai-nilai tersebut seperti bersifat jujur, toleran, mempunyai rasa ingin tahu yang tinggi, memiliki sikap disiplin, saling menghargai dan menghormati, cinta terhadap kedamaian, mempunyai semangat yang gigih, dan paling utama adalah kegiatan keagamaan (religious) dan bertanggung jawab.

Pendidikan karakter yang sudah banyak dicanangkan oleh lembaga pendidikan membuktikan bahwa karakter merupakan hal utama untuk diperhatikan. Terlebih dengan berbagai kasus yang terjadi di masyarakat saat ini seperti :1) meningkatnya kekerasan, 2)penggunaan kata-kata dan bahasa yang buruk, 3) rendahnya rasa hormat kepada orang tua, adanya kecurigaan dan kebencian diantara sesama, rendahnya rasa tanggung jawab terhadap individu dan warga Negara. Lickona dalm Gunawan (2012:28)

Kasus-kasus seperti ini yang tidak diharapkan untuk dicontoh orang banyak, sehingga perlu adanya bimbingan dan keteladanan untuk mengarahkan agar terjadi perubahan sikap dikalangan masyarakat pada umumnya.

Menuntut ilmu pengetahuan adalah kewajiban yang harus dilaksanakan karena sangat berguna bagi kehidupan di dunia dan kelak di akhirat, sebagaimana nabi Muhammad bersabda:

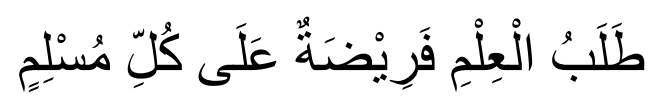

Artinya : Menuntut ilmu itu wajib atas setiap muslim.

Pentingnya pendidikan juga tertera dalam Undang-Undang No. 20 Tahun 2003 yang menyatakan bahwa pendidikan dilakukan secara berjenjang dengan tujuan terjadinya petingkatan potensi pada diri manusia menjadi manusia yang berilmu, berakhlakul karimah, bertanggung jawab dan mandiri.

Peraturan presiden nomor 87 tahun 2017 tentang penguatana pendidikan karakter dilaksanakan dengan menerapkan nilai-nilai pancasila yang meliputu nilai religious, jujur, toleran, disiplin, bekerja keras, kreatif, mandiri, demokrasi, rasa ingin tahu, semngat kebangsaan, peduli social, gemar membaca, peduli lingkungan dan bertanggung jawab.

Menumbuhkan nilai karakter terhadap peserta didik memang tidak semudah membalikkan telapak tangan karena peserta didik berangkat dari keluarga dan kepribadian yang berbeda. Perbedaan karakter dapat dilihat dari sikap, motivasi dan perilaku peserta didik dalam setiap tindakan atau kegiatan sehari-hari. Melalui tindakan potensi yang telah dikenali sebelumnya akan digali dengan proses kebiasaan sehingga bisa membentuk suatu keterampilan yang bermanfaat, karena karakter tidak selalu focus pada ilmu pengetahuan melainkan tindakan yang nantinya akan dilihat dan dicontoh oleh orang lain yang di sebut dengan keteladanan.

Keteladanan berarti memberikan contoh atau sesuatu yang dijadikan acuan oleh orang lain, terlebih seorang guru adalah panutan yang setiap hari dilihat oleh peserta didik, jadi apapun yang dilakukan guru akan dicontoh oleh peserta didik, sehingga seorang teladanan harus memiliki kepribadian dan tingkah laku yang unggul. Teladan dalam mendidik berarti memberi contoh dimana murid akan menirunya, baik dari 
perkataan, perbuatan dan cara berpikir, karena itu pendidik berhati-hati dihadapan peserta didik, menjadi panutan yang layak dicontoh, agar pembentukan karakter menjadi lebih efisien.

Keteladanan sangat efektif dalam membentuk kepribadian peserta didik yang saleh dan shaleha, terlebih manusia memiliki sandaran sebagai suri tauladan yakni Nabi Muhammad saw, sebagaimana firman Allah pada Surah Al-Ahzab ayat 21 yang artinya sebagai berikut:

"Sesungguhnya telah ada pada diri Rasulullah itu suri teladan yang baik bagimu (yaitu) bagi orang yang mengharap (rahmat) Allah dan (kedatangan) hari kiamat dan dia banyak menyembah Allah".

Keteladan guru bermuara pada pola pembiasaan untuk peserta didik. Sebagaimana diungkapkan Hassan dalam Zubaedi (2007) bahwa pendidikan terdiri pembiasaan, pembelajaran dan pembudayaan. Karena pembiasaan peserta didik dapat menunjukan perubahan tingkah laku, melaui pembiasaan peserta didik menjadi pandai dan terampil menghasilkan karya. Melalui pembudayaan juga mampu memasyarakatkan karakter seperti kejujuran, disiplin suka menolong dan kerja sama.

\section{METODE}

Penelitian ini menggunakan pendekatan kualitatif jenis deskriptif berupa kata-kata yang tertulis atau lisan sesuai informasi dan perilaku yang dapat diamati. Landasan penelitian ini adalah fenomenologi, penelitian deskriptif kualitatif adalah penelitian dengan memberikan gambaran secara jelas dan sistematis terkait dengan objek yang diteliti demi memberi informasi dan data yang valid terkait fakta dan fenomena di lapangan.

Lexy J.Moleang (2006) dalam penelitian kualitatif, peneliti atau dengan bantuan orang lain merupakan alat pengumpul data. Hal ini dikarenakan orang-orang bisa sebagai instrument yang sangat luwes dapat menilai keadaan dan mengambil keputusan. Selain itu, hanya manusia sajalah yang dapat berhubungan dengan responden atau objek lainnya dan hanya manusia yang mampu memahami kaitannya denga kenyataan di lapangan.

Proses pemilhan subjek dilakukan menggunkan tekhnik purposive sampling. Proses pengunpulan data dilakukan dengan observasi, wawancara mendalam, dokumentasi, triangulasi, aktivitas dalam analisis data yaitu data reduksi, penyajian data dan menarik kesimpulan.

\section{Teknik Pengunpulan Data}

Untuk memperoleh data yang diperlukan dalam penelitian ini, ada beberapa teknik yang akan peneliti gunakan yaitu:

\section{Observasi}

Observasi yang digunakan yaitu observasi langsung ke lapangan, melihat dan mencata semua tingkah laku, gerak gerik yang dilakukan semua komponen. Observasi atau pengamatan merupakan suatu teknik atau cara mengumpulkan data denga mengadakan pengamatan terhadap kegiatan yang sedang berlangsung. Penelitian ini menggunakan observasi pasif dimana peneliti hanya mengamati kegiatan di lapangan, dengan demikian peneliti tidak terlibat langsung dalam kegiatan. Pada penelitian ini 
penelito mengamati langsung pembiasaan-pembiasaan di sekolah sesuai pedoman observasi.

2. Wawancara Mendalam

Wawancara adalah proses untuk memperoleh keterangan untuk tujuan penelitian dengan cara tanya jawab sambil bertatap muka antara pewawancara dengan informan atau orang yang diwawancarai untuk bertukar informasi ide melalui tanya jawab.

Menurut Moleong (2005:148) wawancara adalah egiatan percakapan dengan maksud tertentu yang dilakukan oleh kedua pihak yaitu pewawancara dan yang diwawancarai. Wawancara dilakukan dengan memberikan pertanyaan-pertanyaan secara langsung dan terbuka kepada informan atau sejumlah pihak yang terkait dan berhubungan dengan masalah yang diteliti untuk memperoleh data yang lengkap dan mendalam.

Wawancara dilakukan dengan menggunakan pedoman wawancara bebas terpimpin. Wawancara bebas terpimpin yaitu cara mengajukan pertanyaan yang dikemukakan bebas, artinya pertanyaan tidak terpaku pada pedoman wawancara tentang masalah-masalah pokok dalam penelitian kemudian dapat dikembangkan sesuai dengan kondisi di lapangan

\section{Dokumentasi}

Dokumen Merupakan catatan peristiwa yang sudah berlalu. Dokumen bisa berbentuk tulisan, gambar, atau karya-karya monumental dari seseorang. Dokumen yang berbentuk tulisan misalnya catatn harian, sejarah kehdupan, cerita, biografi, peraturan, kebijakan. Studi dokumen merupakan pelengkap dari penggunaan metode observasi dan wawancara dalam penelitian kualitatif.

Dokumentasi menurut Rusdin Pohan dalah cara pengumpulan informasi yang didapatkan dari dokumen yakni peninggalan tetulis, arsip ang memiliki keterkaitan dengan masalah yang diteliti. Dokumen adalah catatan tertuls berbagai kegiatan atau peristiwa pada waktu yang lalu. Metode dokumentasi ini sebagai metode pendukung pengumpulan data, karena metode ini dapat diperoleh data-data historis serta data lain yang mendukug penelitian ini.

\section{Triangulasi}

Tekhnik pengumpulan data triangulasi diartikan sebagai teknik pengumpulan data yang bersifat menggabungkan dari berbagai teknik pengumpul data dan sumber data yang telah ada. Bila peneliti melakukan pengumpulan data dengan triangulasi, maka sebenarnya peneliti mengumpulkan data yang sekaligus menguji kredibilitas data dengan berbagai teknik pengumpulan data dan berbagai sumber data.

Pengecekan dengan cara pemeriksaan ulang. Pemeriksaan ulang dilakukan sebeum dan sesudah data dianalisi. Triangulasi merupakan teknik pengecekan keabsahan data yang paling popular dalam penelitian kualitatif yang didasarkan pada kenyataan bahwa cara ini memiliki potensi untuk sekaligus meningkatkan akurasi, kepercayaan, dan kedalaman serta kerincian data.

\section{Teknik Analisa Data}

Penelitian kualitatif memperoleeh data dari berbagai sumber dengan menggunakan teknik pengumpulan data. Data yang diperoleh kemudian dianalisis, sugiyono (2011:244), analisis data adalah adalah proses mencari dan menyusun secara sistematis 
data diperoleh dari hasil wawancara, cacatan lapangan, dan dokumentasi dengan cara mengorganisasakan data ke dalam kategori, menyusun kedalam pola, memilih mana yang penting dan yang akan dipelajari, membuat kesimpulan sehingga mudah untuk dipahami. Analisis data pada penelitian ini dilakukan sejak sebelum memasuki lapangan, selama dilapangan, dan setelah selesai dilapangan.

Peneliti melakukan analisis data dalam dua tahapan yaitu, pertama analisis data pra lapangan yakni analisi dilakukan terhadap studi pendahuluan atau data sekunder, kedua adalah analisis selama dilapangan. Adapun dalam analisis selama dilapangan ini peneliti menguunakan model Miles and Huberman. Analisis data dalam penelitian kualitatif dilakukan pada saat pengumpulan data berlangsung, dan setelah selesai pengumpulan data dalam periode tertentu. Miles and Huberman (Sugiyono, 2014 :246) jugamengungkapkan bahwa analisi data merupakan aktivitas yang dilakukan secara interaktif dan berlangsung secara terus menerus sampai tuntas, sehingga datanya sudah jenuh, aktivitas dalam analisis data yaitu data reduction, data display, dan conlusion drawing/verification.

\section{Kondensasi Data}

Teknik analisis data ini dilakukan sesuai dengan jenis data yang diperoleh. Pada data kualitatatif dipaparkan apaadanya melalui tiga langkah, "qualitative analysis techniques are carried out in three steps, there are: data condensation, data display, conclusion drawing and verification. Data condensation refers to selecting, focusing, simplifying, abstracting, and transforming” (Miles, Huberman, \& Saldaña, 2014). Teknik analisis data secara kualitatif dilakukan melalui tiga langkah, yaitu: kondensasi data, menyajikan data, menarik kesimpulan dan verivikasi data.

Kondensai data dilakukan dengan cara menyeleksi, menfokuskan, menyederhanakan, mengabtraksikan, dan mentransformasi data yang terdapat pada field notes atau catatan lapangan hasil penelitian. Proses menyeleksi data dilakukan dengan cara menentukan dimensi-dimensi yang lebih penting, bermakna, seluruh informasi tersebut dikumpulkan untuk memerkuah penelitian. Proses menfokuskan (focusing), Focus pada tujuan penelitian sehingga data-data yang dianggap asing, belum memiliki pola, dan tidak sesuai dengan tujuan penelitian. Dengan demikian dapat menghasilkan data yang lebih terarah dan terfokus ke temuan yang dimaksudkan.

\section{Data Display}

Mendisplay data akan memudahkan untuk memahami apa yang terjadi melalui penyajian data, maka data terorganisasikan, tersusun dalam pola hubungan, sehingga semakin mudah dipahami. Penyajian data dilakukan dalam bentuk teks yang bersifat naratif. Mendisplay data memudahkan untuk memahami apa yang terjadi, merencanakan apa yang telah dipahami.

\section{Penarikan Kesimpulan (verifikasi)}

Kesimpulan dalam penelitian kualitatif merupakan temuan baru yang sebelumnya belum pernah ada, temuan dapat berupa deskripsi atau gambaran suatu obyek yang sebelumnya masih belum jelas menjadi jelas dan akurat dapat beupa hubungan kausal atau interaktif hipotesis atau teori. 


\section{Teknik Keabsahan Data}

Pengabsahan data merupakan salah satufactor yang sangat penting dalam penelitian kualitatif, karena tanpa pengabsahan data yang diperoleh dari lapangan maka peneliti akan menjawab kesulitan dalam mempertanggung jawabkan hasil penelitiannya. Dalam hal ini keabsahan data peneliti menggunakan metode triangulasi.

Triangulasi merupakan teknik peemeriksaaan keabsahan data yang memanfaatkan sesuatu yang lain. Selain itu triangulasi menurut (Moleong 2017:332). Mengukapkan bahwa triangulasi adalah cara terbaik untuk menghilangkan perbedaan konstruksi kenyataan yang ada dalam konteks atau studi sewaktu mengumpulkan data tentang berbagai kejadian dan hubungan dari berbagai pandangan. Dengan kata lain temuannya dengan jalan membandingkan dengan berbagai bahwa triangulasi peneliti dapat merecheck temuannya dengan jalan membandingkan dengan berbagai sumber, metode, atau kteori dengna menggunakan triangulasi sumber, triangulasi teknik, triangulasi waktu.

\section{HASIL}

Karakter adalah sikap pribadi yang stabil, hasil proses konsolidasi secara progresif dan dinamis, integrasi pernyataan dan tindakan. Pendidikan karalter mengajarkan kebiasaan cara berpikir dan berperilaku yang membantu individu untuk hidupdan bekerja sama dalam keluarga, pelaksanaan pendidikan karakter harus dipikul oleh semua pihak, termasuk kepala sekolah, guru, staf tata usaha, penjaga kantin, bahkan orang tua dirumah.

Khususunya di sekolah keteladanan merupakan hal yang paling penting di contohkan melaui tindakan seorang guru, jadi apa yang dilakukan guru dilihat oleh murid, ketika guru selalu mengucapkan kata tolong dan maaf, maka ssecara tidak langsung akan dilakukan pula oleh murid untuk melatih kebiasaan dalam melakukan halhal yang mengarah pada nilai-nilai karakter. Pembiasaan untuk bersikap baik, pembiasaan untuk berprilaku jujur, malu bersikap malas, tolong menolong, malu membiarkan lingkungan kotor, karena karakter tidak terbentuk secara instan tetapi harus dilatih serius dan tekun malalui proses kebiasaan secara terus menerus dan beulang-ulang agar mencapai bentuk karakter yang ideal dan unggul.

M.Mifta (2013) menyatakan bahwa dalam proses pembelajaran, murid dilatih dan dibiasakan menelaah secara kritis nilai-nilai dan menimbang isu-isu moral serta etika bagi pengembangan kepedulian tentang nilai dan hakikat hidup bermasyarakat, berinteraksi dan berinteraksi.

Semua pembiasaan yang dilakukan disekolah berawal dari bentuk keteladanan guru, guru yang senantiasa memberikan contoh mulai pagi sampai pulang sekolah, menjemput peserta didik membuktikan bentuk kedisiplinan yang dilakukan datang lebih awal, dan melakukan berbagai kegiatan yang dapat membentuk karakter sebagai cerminan untuk dibiasakan murid mulai dari kerapihan, kebersihan, kedisiplinan, serta menghargai waktu.

Paparan data tersebut, hasil penelitian menunjukkan bahwa keteladanan guru dilakukan melalui tindakan, guru lebih cenderung melakukan dari pada menyuruh, dengan maksud bahwa peserta didik akan sadar dengan sendirinya ketika mereka melihat dibandingkan dengan memberikan perintah, seperti kedisiplinan, menjaga kebersihan, adil, bijaksana, sopan, santun dalam bertutur, mengucapkan kata maaf dan selalu mengucapkan kata tolong sebelum meminta bantuan, dengan cara ini peserta didik akan melihat apa yang dilakukan oleh gurunya dan nantinya akan dibiasakan dalam kehidupan 
sehari-hari, contoh kecil yang kadang orang lain tidak memperhatikan yaitu makan dan minm posisi duduk, menyimpan sepatu pada tempat yang disediakan, dalam hl ini gurulah yang terlebih dahulu melakukan yang nantinya akan di teladani oleh peserta didik.

Sejalan dengan visi dan misi yang menjadi acuan sekolah dalam hal ini adalah “ mendidik insan kreatif, inovatif, mandiri, sopan dalam bertindak, santun dalam bertutur. Semua ini bisa terjadi karena adanya keteladanan dari guru yang akhirnya bermuara pada pembiasaan murid.

Pembiasaan merupakan salah satu cara untuk mencapai tujuan. Sebuah tujuan tidak akan tercapai jika pembiasaan-pembiasaan tidak mendapat keteladanan dari guru, direncakan dengan konsep dan analisa dilapangan secara nyata. Pentingnya pembiasaan bisa dijadikan sebagai landasan penerapan, olehnya penerapan keteladanan guru harus terkonsep dan terlaksana dengan baik agar tujuan tercapai sesuai harapan. Berbagai kegiatan pun dilakukan peserta didik sebagai budaya atau kegiatan pembiasaan seperti: disiplin, datang ke sekolah tepat waktu, membiasakan salam dan salim,senyum sapa, melakukan shalat dhuha dengan bimbingan guru, shalat dhuhur berjamaah dan tadarusan, menghafal surah pendek. Pembiasaan kecil juga diajarkan misalnya turun tangga melewati arah kiri, minum tidak dalam posisi berdiri, membaca doa sebelum dan sesudah makan maupun belajar, tak kalah penting juga dibiasakan mengucapkan kata terima kasih maupun kata pujian yang lain. Semua ini dilakukan untuk mengarahkan dan membetuk karakter murid menjadi lebih disiplin, membiasakan bersikap sopan, santun, ramah, jujur, mandiri, kreatif, dan terpenting murid mampu membuang sampah pada tempatnya artinya murid sadar akan kebersihan itu sangat penting.

Paparan keteladana guru dan pembiasan yang dilakukan tentu menumbulkan dampak bagi peserta didik. Pembelajaran berkarakter khususnya dalam menumbuhkan nilai-nila karakter, baik guru maupun peserta didik pastinya ada hasil yang dimunculkan baik langsung maupun tidak langsung.

Dampak yang ditimbulkan dari keteladanan guru dalam mendidik yang didasari ajaran agama sangat positif untuk dibiasakan murid dalam kehidupan sehari-hari, jadi selama guru telaten dan sungguh-sungguh dalam mendidik, memberikan contoh terbaik maka kebiasaan baik pada peserta didik akan terlihat jelas. Dampak ini akan terbawa secara sadar dalam kegiatan sehari-hari, jika guru memberikan contoh yang baik maka anak didik akan menirunya, maka tidaklah salah jika dikatakan bahwa sejatinya guru adalah teladan yang baik dilingkungan sekolah, namun dalam hal keteladanan guru dan pembiasaan tidak akan dikatakan baik jika tidak dievaluasi secara rutin, baik evaluasi untuk guru maupun peserta didik, ini dilakukan agar ada pertimbangan jika ada kekuraangan untuk perbaikan kembali.

Keteladan guru juga berawal dari pembiasaan, misalnya dalam kelas ataupun di lingkungan sekolah, guru selalu mengucapkan terima kasih saat mengajar di kelas, sehingga secara tidak langsung murid mendengar dan akan terbiasa mengucapkan terima kasih baik dilingkungan sekolah maupun di rumah, pada dasarnya apa yang dilakukan oleh anak sesuai dengan apa yang didengar dan dilihat. Sehingga di lingkungan sekolah guru harus menjadi contoh yang baik.

\section{PEMBAHASAN}

Anak merupakan generasi penerus bangsa, maka baik buruknya bangsa dimasa depan ditentukan oleh anak dimasa sekarang. Sehingga pelaksanaan keteladanan ini tidak lepas dari perencanaan terlebih dahulu. Salah satu contoh dalam membentuk karakter adalah dengan menyambut kedatanagn murid, Nur Arif (2018) menyampaikan bahwa 
menfaat menyambut kedatangan peserta didik adalah: 1) Kepala sekolah, guru, tenaga kependidikan, murid dan orang tua murid dapat saling mengenal dan mendoakan setiap hari, 2) Dapat tercipta hubungan yang harmonis, 3) Dapat tercipta komunikasi yang efektif antara kepala sekolah, guru, tenaga kependidikan, murid dan orang tua.

Manfaat tersebut terdapat nilai-nilai spiritual, nilai moral, nilai social dan juga niai budaya, karema agama mengajarkan agar kita untuk mengucapkan salam dan berjabat tangan ketika bertemu sesame muslim.

Junaedi (2018) mengatakan bahwa manfaat lain dari shalat duha adalah disamping bagian darikekuatan untuk memperoleh rezki, shalat duha juga merupakan waktu untuk mengingat Allah SWT karena diwaktu tersebut kebanyakan orang-orang lengah berdzikir atau ingan kepada Rabb-Nya.

Selanjutnya adalah shalat duhur berjamaah, shalat adalah bentuk pembiasaan yang dilakukan agar murid terbiasa shalat dengan tepat waktu dan juga secara berjamaah, tentu dipahami bahwa shalat adalah kewajiban lima waktu yang wajib ditunaikan oleh umat muslim.

Semua yang telah dicontohkan oleh guru akan menjadi kebiasaan oleh peserta didik, seperti guru yang berperilaku sopan, santun dalam berkata, maka begitu pula yang akan dilakukan oleh peserta didik, dari hasil penelitian beberapa nilai karakter yang dilaksanakan sebagai pembiasaan seperti didiplin, membudayakan senyum salam salim dan sapa, bertanggung jawab,jujur, mandiri, dan sadar akan waktu beribadah (shalat) berjamaah, tekun membacakan ayat suci al-quran, memperhatikan kebersihan. Seperti yang dikemukakan oleh Innayah (2012) bahwa membentuk karakter tidak mudah dilaksanakan, oleh karena itu di butuhkan strategi dalam pendidikan karakter dilakukan melalui keteladanan, sikap, dan penanaman kedisiplinan, menciptakan suasana kondusif.

Selain nilai spiritual, niali yang ditumbuhkan adalah nilai budaya, dalam hal ini yang dilakukan peserta didik lewat bimbingan kegiatan literasi. Aeni (2014) mengungkapkan bahwa sebagai guru teladan yang harus memahami dan mencontohkan pembiasaan harus menunjukkan keteladanan yang unggul, mengarahkan dan memberikan bimbingan, memberikan motivasi melalui hati yang tulus, menuju proses pembiasaan.

Undang-undang no 43 tahun 2007 tentang perpustakaan tertuang dengan jelas aturan-aturan mengenai hak, kewajiban, kewenangan standar nasional, kerjasama mmbudayakan kegiatan membaca dan saknsi. Undang-undang tersebut menjelaskan kegiatan tersebut untuk mencerdaskan kehidupan bangsa.

\section{SIMPULAN DAN SARAN}

Penjelasan hasil penelitian diatas disimpulkan bahwa pembentukan karakter berbasis keteladanan guru dan pembiasaan murid terlaksana dengan baik melaui tindakan atau perbuatan yang bisa menarik perhatian peserta didik untuk melihat, dan mengabil pelajaran dari tindakan tersebut, peserta didik akan sadar secara mandiri tanpa perintah bahwa apa yang dilakukan oleh guru adalah contoh yang juga harus dilakukan oleh semua individu yang ada di sekolah, mulai datang ke sekolah sampai pulang, memberikan bimbingan, pembelajaran dan arahan yang menyenangkan agar peserta didik termotifasi dan percaya diri, mengoptimalkan strategi dalam membentuk nilai-nilai karakter lewat tindakan sehari-hari sebagai contoh shalat dhuha, menjaga kualitas diri di depan peserta didik, santun dalam bertutur, ucapan kata maaf dan tolong yang akan selalu didengar oleh peserta didik. 
Pembentukan karakter berbasis pembiasaan berawal dari keteladan yang dilakukan oleh guru, karena dari keteladanan akan menjadi suatu kebiasaan. Sehingga apa yang diperlihatkan oleh guru maka itulah yang akan dicontoh oleh murid, pembiasaan ini adalah landasan oleh guru untuk murid, pembiasaan - pembiasaan yang dilakukan untuk pembentukan karakter murid di SIT Al Biruni Makassar yaitu : pembiasaan salam, salim, pembiasaan adab adab makan, disiplin, berucap kata maaf dan tolong, mandiri, percaya diri, jujur,dan religious.

Dampak pembentukan karakter berbasis keteladanan guru dan pembiasaan murid di SIT Al Biruni telah terlihat dalam kegiatan sehari-hari dilingkungan sekolah, dan ini membuktikan bahwa keteladanan guru yang bermuara pada pembiasaan memberikan dampak positif yang bisa diaplikasikan dalam kehidupan sehari-hari, ini menunjukan keberhasilan membentuk karakter dengan dampak yang ditimbulkan setelah diberlakukan keteladanan guru dan pembiasaan murid melahirkan karakter seperti menciptakan manusia kreatif, meningkatkan keimanan, merubah sikap menjadi lebih baik, sadar akan pentingnya literasi dan cinta lingkungan melalui kegiatan social.

\section{DAFTAR RUJUKAN}

Alquran dan Terjemahnya (Jakarta: yayasan penyelenggara dan Penterjemah al-Qur'an, 1971).

Aeni Nur (2014) Pendidikan Karakter Untuk Siswa SD dalam Persfektif Islam. jurnal.upi.edu/mimbar-sekolah-dasar. Vol 1 Nomor 1 (/). Hal. 50-57

Arif, Nur. (2018). Rahasia sukses pendidikan Karakter di sekolah.:CV kaaffah Learning center Sulawesi Selatan.

Gunawa, Heri. (2012). Pendidikan Karakter, Konsep dan Implementasi. Bandung : Alfabeta

Innayah. (2012). “ Dongeng Anak Nusantara radio edukasi (RE) sebagai media untuk Penanaman Karakter bangsa' dalam Jurnal teknodik; terakreditasi LIPI No. 464/AU1/P2MI-LIPI/06/2012.

Junaedi. (2018). Menjadi Guru yang dirinduinya. Surabaya : CV Pustaka Media Guru .

Miftah.M. 2013. Pengembangan Karakter Anak melalui Pembelajaran Ilmu Sosial. Jurnal Pendidikan Karakter. Nomor 2. Juni 2013.

Miles, M. B., Huberman, A. M., \& Saldaña, J. (2014). Qualitative data analysis: A methods sourcebook. 3rd. Thousand Oaks, CA: Sage.

Moleong, Lexy. (2006). Metodologi Penelitian Kualitatifedisi Revisi. Bandung:PT Remaja Rosdakarya.

Sistem Pendidikan Nasional (UU RI No.20 tahun 2013, (Jakarta: Sinar Grafika 2009)hal 7.

Tafsir A (2005). Ilmu Pendidikan Dalam Persfektif Islam. Bandung: PT. Remaja Rosdakarya

Zubaedi (2011) Desain Pendidikan Karakter: Konsepsi dan Aplikasinya dalam Lembaga pendidikan: Jakarta: Kharisma Putra Utama. 